\title{
Assessment of the effects of ozone exposure and plant competition on the reproductive ability of three therophytic clover species from Iberian pastures
}

\author{
B.S. Gimeno*, V. Bermejo, J. Sanz, D. de la Torre, J.M. Gil \\ Ecotoxicology of Air Pollution, CIEMAT (Ed. 70). Avda, Complutense 22, Madrid 28040, Spain
}

\begin{abstract}
Ozone $\left(\mathrm{O}_{3}\right)$ phytototoxicity has been reported on a wide range of crops and wild Central European plant species, however no information has been provided regarding the sensitivity of plant species from dehesa Mediterranean therophytic grasslands in spite of their great plant species richness and the high $\mathrm{O}_{3}$ levels that are recorded in this area. A study was carried out in open-top chambers (OTCs) to assess the effects of $\mathrm{O}_{3}$ and competition on the reproductive ability of three clover species: Trifolium cherleri, Trifolium subterraneum and Trifolium striatum. A phytometer approach was followed, therefore plants of these species were grown in mesoscosms composed of monocultures of four plants of each species, of three plants of each species competing against a Briza maxima individual or of a single plant of each clover species competing with three $B$. maxima plants. Three $\mathrm{O}_{3}$ treatments were adopted: charcoal filtered air (CFA), non-filtered air (NFA) and non-filtered air supplemented with $40 \mathrm{nll}^{-1}$ of $\mathrm{O}_{3}(\mathrm{NFA}+$ ). The different mesocosms were exposed to the different $\mathrm{O}_{3}$ treatments for 45 days and then they remained in the open. Ozone exposure caused reductions in the flower biomass of the three clover species assessed. In the case of $T$. cherleri and T. subterraneum this effect was found following their exposure to the different $\mathrm{O}_{3}$ treatments during their vegetative period. An attenuation of these effects was found when the plants remained in the open. Ozone-induced detrimental effects on the seed output of $T$. striatum were also observed. The flower biomass of the clover plants grown in monocultures was greater than when competing with one or three B. maxima individuals. An increased flower biomass was found in the CFA monoculture mesocosms of T. cherleri when compared with the remaining mesocosms, once the plants were exposed in the open for 60 days. The implications of these effects on the performance of dehesa acid grasslands and for the definition of $\mathrm{O}_{3}$ critical levels is discussed.
\end{abstract}

Keywords: Seed production; Flower biomass; Mediterranean grasslands; Dehesa; Critical levels

\section{Introduction}

Grassland ecosystems are particularly endangered by the interaction of global change components such as alterations in land-use changes, climate, nitrogen deposition, biotic exchange or atmospheric carbon dioxide
(Sala et al., 2000). Tropospheric ozone $\left(\mathrm{O}_{3}\right)$ is also a global change compound that might harm these ecosystems at the European scale since it reaches phytotoxic levels in rural areas (EMEP, 2002). Ozoneinduced detrimental effects on grassland species from Northern and Central Europe have been reported, involving the induction of visible injury, reductions in growth-related parameters or alterations in plant competitive ability (Davison and Barnes, 1998). However, there is scarce information regarding $\mathrm{O}_{3}$ impacts on Mediterranean grasslands although they present a 
remarkable plant species richness, as is the case for dehesa-type grasslands (Pineda et al., 1981), and the Mediterranean basin has been considered as an "hyperhot" candidate for conservation support (Myers et al., 2000).

There is evidence that high $\mathrm{O}_{3}$ levels are reached in the dehesas of the central Iberian rangelands (Plaza et al., 1997; Palacios et al., 2002). These ecosystems are agrosylvo-pastoral systems composed of cleared oak woodlands with an annual grassland understorey and represent an example of sustainable management of natural resources in the Iberian Peninsula, covering agricultural, timber and extensive livestock exploitation (Marañón, 1988). Large spatial and temporal fluctuations in their floristic composition occur depending on tree coverage, slope-valley gradients, grazing pressure, regular ploughing and meteorological fluctuations (Peco et al., 1998a).

The most characteristic herbaceous species of therophytic dehesa grasslands on acid soils belong to the Leguminosae or Graminae families; both taxa have different roles in ecosystem function, mainly in nitrogen cycling, and they also have dissimilar nutritive implications for the livestock grazing on them. A screening assessment based on visible injury indicated that dehesa clover species, such as Trifolium cheleri, Trifolium striatum and Trifolium subterraneum, were more sensitive to $\mathrm{O}_{3}$ than the grasses of these ecosystems (Bermejo et al., 2003). These findings are in agreement with the reports provided by other authors in regards to the sensitivity of the Trifolium genus to $\mathrm{O}_{3}$ (Nussbaum et al., 1995; Warwick and Taylor, 1995; Bungener et al., 1999). However, while the ecological significance of visible symptoms and reduced biomass is unknown, potential $\mathrm{O}_{3}$ effects on plant reproductive ability (see review by Black et al., 2000) are of undoubted ecological relevance (Davison and Barnes, 1998). This is specially valid for Mediterranean rangelands dominated by therophytes as a great correspondence between the soil seed bank and the plant species present in these ecosystems has been found (Peco et al., 1998b). Moreover, it is difficult to scale-up these results to plant community level since interactions of this pollutant with other abiotic and biotic factors are likely to occur. Experiments involving plant competition are needed to predict dynamic changes in plant communities under $\mathrm{O}_{3}$ stress as this pollutant has been reported to induce changes in the species composition of grassland communities (Fuhrer et al., 1994; Ashmore et al., 1995). Also, $\mathrm{O}_{3}$ exposure pattern might influence plant responsiveness as carryover effects of this pollutant were found when therophytes from dehesa grasslands were exposed during the earlier stages of their short life- span (Bermejo et al., 2003).

The United Nations-Economic Commission for Europe Convention on Long-Range Transboundary
Air Pollution (UN ECE CLRTAP) has promoted the establishment of $\mathrm{O}_{3}$ critical levels for plant receptors. Critical level is defined as the pollutant concentration above which direct effects on receptors such as plants, ecosystems or materials, may occur according to present knowledge (UN ECE, 1988). The definition of $\mathrm{O}_{3}$ critical levels for seminatural vegetation is a difficult matter because of the great diversity of these receptors, the complexity of interactions between $\mathrm{O}_{3}$ effects and environmental conditions and also due to the lack of experimental data (Fuhrer et al., 2003). Sensitive taxa and ecosystems should be identified to establish sound critical levels for seminatural vegetation (Davison and Barnes, 1998). Present $\mathrm{O}_{3}$ critical level for this receptor is established as an AOT40 (Accumulated exposure over $40 \mathrm{nl}^{-1} \mathrm{~h}$ ) value of $3000 \mathrm{nl}^{-1} \mathrm{~h}$ for three consecutive months, although a great uncertainty in this estimate was found regarding both the exposure index and its value (Ashmore and Franzaring, 2003).

The aims of this work were to determine whether an early $\mathrm{O}_{3}$ exposure would induce detrimental effects in the reproductive ability of three clover therophytes from dehesa acidic grasslands and to ascertain whether plant competition modulates this impact. An analysis is also made to find the most suitable $\mathrm{O}_{3}$ exposure index best related with the response of these species aiming to contribute to the definition of $\mathrm{O}_{3}$ critical levels since an urgent need in providing information on the response of Mediterranean species to $\mathrm{O}_{3}$ has been identified (Ashmore and Franzaring, 2003).

\section{Materials and methods}

\subsection{Plant material}

Three $\mathrm{O}_{3}$-sensitive clover species, $T$. cherleri, $T$. subterraneum and $T$. striatum, from dehesa acidic grasslands were grown in monoculture or in competition with an $\mathrm{O}_{3}$-resistant grass species from the same ecosystems (Briza maxima). The $\mathrm{O}_{3}$ sensitivity of these species was assessed in a former experiment (Bermejo et al., 2003). The germoplasm bank of the Consejería de Agricultura y Medio Ambiente de la Comunidad Autónoma de Extremadura supplied the clover seeds. The certified seed origin coordinates for $T$. cherleri and T. striatum were $38^{\circ} 22^{\prime} 0^{\circ} 64^{\prime} \mathrm{W}$, and $38^{\circ} 55^{\prime} \mathrm{N}^{\prime} 0^{\circ} 56^{\prime} \mathrm{W}$, respectively (Badajoz, Spain). The Spanish $T$. subterraneum cv. Zujar was used in the experiments while B. maxima seeds were collected at the Moncalvillo Dehesa in Guadalix de la Sierra (Madrid, $40^{\circ} 40^{\prime} \mathrm{N} 03^{\circ} 46^{\prime} \mathrm{W}$ ).

The clover seeds of the different species were immersed for $24 \mathrm{~h}$ in a Germinator ${ }^{\circledR}$ solution (AgroOrgánicos Mediterráneos S.L., Spain) to ensure a homogeneous germination. When seeds were swollen they were sown in a medium of $50 \%$ neutral peat and 
$50 \%$ vermiculite substrate and grown in a greenhouse. The B. maxima seeds did not experience any pretreatment and were sown using the same substrate. One month after their emergence, plants were transplanted to 61 pots using a $50 \%$ neutral peat, $25 \%$ vermiculite and $25 \%$ perlite substrate supplemented with $2 \mathrm{~kg} \mathrm{~m}^{-3}$ of a slow-release fertiliser/10-12 months, NPK:12/25/12. The phytometer approach was followed to simulate plant competition in the field aiming to avoid discussion about replacement or additive designs (De Witt, 1960; Snaydon, 1991; Hamilton, 1994). Three mesoscosm types were defined: (a) Four-plant monocultures of $T$. cherleri (A4), T. striatum (D4) and T. subterraneum (F4); (b) mixtures of $3 \mathrm{~B}$. maxima plants growing with a central plant of $T$. cherleri (3B1A), T. striatum (3B1D) or $T$. subterraneum $(3 \mathrm{~B} 1 \mathrm{~F})$ and $(\mathrm{c})$ mixtures of $1 \mathrm{~B}$. maxima plant growing with 3 plants of $T$. cherleri (3A1B) or $T$. striatum (3D1B). Plants were placed in each pot in the centre and the vertices of a $10 \mathrm{~cm}$ side triangle to avoid potential edge-derived effects. Pots were spaced in the chambers avoiding shading effects between plants of different pots. Daily irrigation of plant material was carried out from the start of the experiment using a droplet system to ensure a homogeneous irrigation within each mesocosms.

\subsection{Experimental design}

The experiment was performed at an open-top chamber (OTC) experimental field located in Sant Jaume d'Enveija, Spain $\left(40^{\circ} 41^{\prime} \mathrm{N}, 0^{\circ} 47^{\prime} \mathrm{E}\right)$. When plant height was $4-5 \mathrm{~cm}$ and $8-10 \mathrm{~cm}$ for clover plants and $B$. maxima, respectively, they were transplanted into pots and transferred into slightly modified NCLAN-type OTCs (Gimeno et al., 1999) to $3 \mathrm{O}_{3}$ treatments: charcoal-filtered air (CFA) presenting subphytotoxic
$\mathrm{O}_{3}$ levels, non-filtered air (NFA), and non-filtered air supplemented with $40 \mathrm{nll}^{-1} \mathrm{O}_{3}$ from 07:00 to 17:00 (GMT) 5 days week ${ }^{-1}(\mathrm{NFA}+)$. Ozone fumigation started a week after plant material was introduced in the chambers, to enable their adaptation to the new environmental conditions. Three chambers per treatment were used following a randomised complete block design. A complete description of the operation of the fumigation and air-quality monitoring systems is provided in Alonso et al. (2001). The different mesocosms were exposed during 45 days to the different $\mathrm{O}_{3}$ treatments, then the chamber plastics were removed and all plant material remained in the open exposed to ambient $\mathrm{O}_{3}$ levels. Flower collection was carried out following their formation and maturation, which was both species and time-dependent. Three replicates of each for each mesocosm-type per chamber ( 9 replicates per each combination of mesocosm and $\mathrm{O}_{3}$ treatment) were involved in each harvest for each species.

Flowering was first recorded in $T$. striatum, the first evaluation of flower production was carried out once the plant material was already exposed for 45 days in the OTCs. At this stage inflorescences were not developed in $T$. subterraneum and $T$. cherleri. A second assessment of flower dry weight was carried out again in $T$. striatum once the plants remained in the open for 30 days following their previous exposure in the OTCs. This assessment was coincidental with the first evaluation of the flower production of $T$. subterraneum and $T$. cherleri. An additional assessment was carried out for $T$. cherleri once the plants remained in the open for 57 days after their exposure in the OTCs. In each assessment the flowers were carefully excised and dried at $65^{\circ} \mathrm{C}$ to constant weight.

Table 1

Experimental protocol followed during the experiment

\begin{tabular}{|c|c|c|c|c|c|c|c|c|}
\hline & \multirow[t]{2}{*}{ Parameters } & \multirow[t]{2}{*}{ Sowing dates } & \multirow[t]{2}{*}{ Start of $\mathrm{O}_{3}$ treatments } & \multirow[t]{2}{*}{ Evaluation date } & \multirow[t]{2}{*}{$\mathrm{DAS}^{\mathrm{a}}$} & \multicolumn{3}{|c|}{$\operatorname{AOT} 40^{\mathrm{b}}\left(\mathrm{nl} \mathrm{l}^{-1} \mathrm{~h}\right)$} \\
\hline & & & & & & $\mathrm{CFA}$ & NFA & $\mathrm{NFA}+$ \\
\hline \multirow[t]{2}{*}{ T.cherleri } & Flowers & $23 / 04$ & $28 / 05$ & $8 / 08$ & 72 & $1518(0)$ & $4956(2662)$ & $17,118(13,203)$ \\
\hline & Flowers & $23 / 04$ & $28 / 05$ & $8 / 09$ & 102 & $2213(0)$ & $6071(2662)$ & $18,117(13,203)$ \\
\hline \multirow[t]{3}{*}{ T.striatum } & Flowers & $23 / 04$ & $30 / 05$ & $14 / 07$ & 45 & $0(0)$ & $2404(2404)$ & $13,390(13,390)$ \\
\hline & Flowers + Seeds & $23 / 04$ & $30 / 05$ & $13 / 08$ & 75 & $1684(0)$ & $4822(2404)$ & $16,958(13,390)$ \\
\hline & Seeds & $23 / 04$ & $30 / 05$ & $5 / 09$ & 98 & $2398(0)$ & $5630(2404)$ & $17,683(13,390)$ \\
\hline T.subterraneum & Flowers & $25 / 04$ & $31 / 05$ & $18 / 08$ & 79 & $1863(0)$ & $4842(2228)$ & $16,972(14,161)$ \\
\hline
\end{tabular}

The figures in brackets correspond to the accumulated $\mathrm{O}_{3}$ exposure during just the 45 days the plants were exposed to the different treatments in the open-top chambers. $\mathrm{CFA}=$ charcoal-filtered air; NFA $=$ Non-filtered air; NFA $+=$ Non-filtered air supplemented with $40 \mathrm{nl}^{-1}$.

${ }^{a}$ Days after the start of the experiment.

${ }^{b}$ Value of the accumulated $\mathrm{O}_{3}$ exposure index AOT40 throughout the experiment. 
Two assessments were carried out to determine the seed output of $T$. striatum plants. The first evaluation was coincidental with the second flower harvest of $T$. striatum plants; at this stage the seeds were segregated from the flowers by carefully rubbing the inflorescences on a sandpaper and dried at room temperature for a month until a constant weight was reached. The second evaluation was carried out 23 days later (see Table 1), flower structures were completely dry and the seeds were collected and weighted following the aforementioned procedures.

Details on the experimental protocol, the dates the plants were introduced in the chambers, the length of $\mathrm{O}_{3}$ exposure in the different treatments and the dates when flower and seed assessments were carried out for the different species are presented in Table 1.

\subsection{Ozone exposure indices}

As time of germination and onset of flowering differed between species (thus presenting different exposure durations), $\mathrm{O}_{3}$ exposure indices were calculated separately for each species and harvest period. The $\mathrm{O}_{3}$ exposure for a given treatment was calculated as an average for all mesocosm types (see Table 1). The AOT40, AOT30 (accumulated exposure over the cut-off of $30 \mathrm{nl}^{-1}$ ), AOT60 (accumulated exposure over the cut-off of $60 \mathrm{nll}^{-1}$ ) and the number of hours presenting $\mathrm{O}_{3}$ levels above 30,40 and $60 \mathrm{nl}^{-1}$ (NUM30, NUM40 and NUM60, respectively) were also calculated. In addition, $\mathrm{O}_{3}$ 10-h mean from 07:00 to 17:00 GMT (M10), the 24-h $\mathrm{O}_{3}$ mean (M24), the number of days where the $\mathrm{O}_{3}$ daily mean exceeded $33 \mathrm{nl}^{-1}$ (D33) and the number of hourly averages exceeding $100 \mathrm{nll}^{-1}$ (NUM100) were also determined.

\subsection{Statistical analyses}

Ozone and $B$. maxima competition effects on the three clover species assessed in this experiment were analysed using a two-way ANOVA for each species, considering mesocosms-type and $\mathrm{O}_{3}$ treatment as factors. When significant differences between treatments were found $(p<0.05)$, mean differences were assessed using the Tukey honest significant difference test (HSD) for unequal sample sizes. For $p<0.1$ values, differences between treatments were considered as trends. The combined analyses of the effects of these two factors on the flower biomass production of the three Trifolium species involved in the experiment was also performed. The validation process and the assumptions of analyses of variance followed using Shappiro-Wilk's W and Levenne tests to check the normal distribution and homogeneous variance, respectively. When non-compliance with ANOVA assumptions was found log transformations of data were carried out. The relationship between relative flower biomass and the different $\mathrm{O}_{3}$ exposure indices was analysed using Pearson's Correlation Index and the level of significance was determined using the $t$-student test. All statistical analyses were performed using the Statistica 97 software.

\section{Results and discussion}

Mean air vapour pressure deficit (VPD) during the period the plants were exposed in the chambers and in the open was 0.52 and $0.57 \mathrm{kPa}$, respectively. Ozone levels in the CFA chambers was always below $15 \mathrm{nl}^{-1}$, the 10 -h mean was 41 and $55 \mathrm{nll}^{-1}$ in the NFA and $\mathrm{NFA}+$ chambers, respectively. The AOT40 values corresponding to the different treatments are presented in Table 1.

The three clover species involved in the experiment were very sensitive to $\mathrm{O}_{3}$, in agreement with other experimental results reporting the great sensitivity of Mediterranean clover species (Madkour and Laurence, 2002; Bermejo et al., 2003). The experimental findings obtained for the different clover species are presented separately, a combined analysis of the response of the three clover species is also presented. Since plant response was consistently related with its early exposure to $\mathrm{O}_{3}$ for 45 days in the OTCs, the AOT40 values presented in the text correspond to that particular period.

\subsection{T. cherleri}

Both $\mathrm{O}_{3}$ and mesocosm-type had a significant impact ( $p<0.01$ in both cases) on the flower dry weight corresponding to the first flower harvest of $T$. cherleri plants, when plant material remained in the open for 30 days after being exposed to the different $\mathrm{O}_{3}$ treatments in the chambers. However, no significant interaction between both factors was observed (Fig 1a). Flower output in the CFA chambers was $52 \%$ greater than in the NFA and NFA + OTCs, no differences were found between the latter two treatments. These results indicate that the exposure of this species to $\mathrm{O}_{3}$ during its vegetative period influences its flower production, the AOT40 values related with the observed effects were 2662 and $13203 \mathrm{nl}^{-1} \mathrm{~h}$ for NFA and NFA + treatment, respectively. Regarding competition, the total flower dry weight of $T$. cherleri was $48 \%$ greater when grown in monoculture than when grown together with 1 or 3 B. maxima plants.

Similar results were still found when the results from the second flower harvest were analysed (Fig. 1b). At this stage, the plants remained in the open for 60 days after being exposed to the different $\mathrm{O}_{3}$ treatments in the OTCs. Ozone and mesocosm-type significantly $(p<0.001)$ influenced the flower biomass of this species. 
Trifolium cherleri- $1^{\text {st }}$ flower harvest (72 DAS)

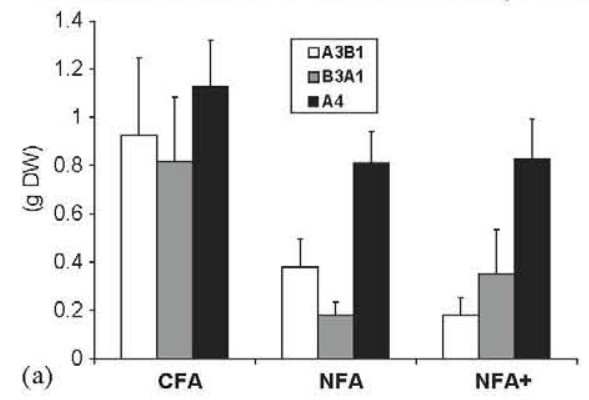

Trifolium cherleri- $2^{\text {nd }}$ flower harvest (102 DAS)

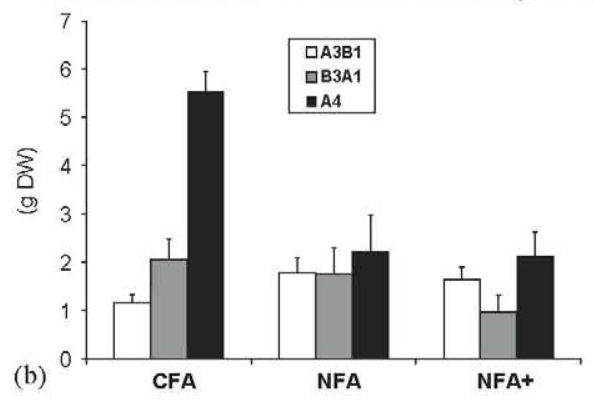

Trifolium subterraneum (79 DAS)

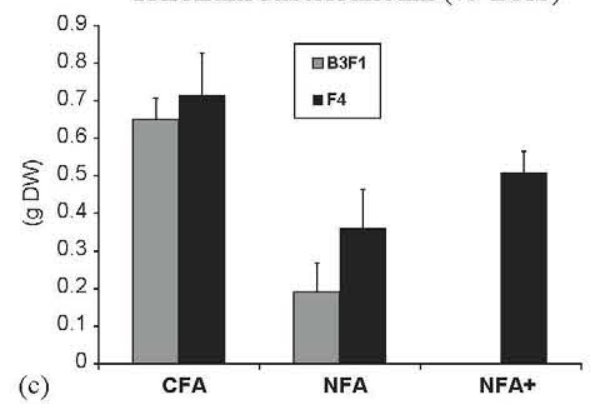

Trifolium striatum $-1^{\text {st }}$ flower harvest (45 DAS)

Trifolium striatum $-2^{\text {nd }}$ flower harvest (75 DAS)
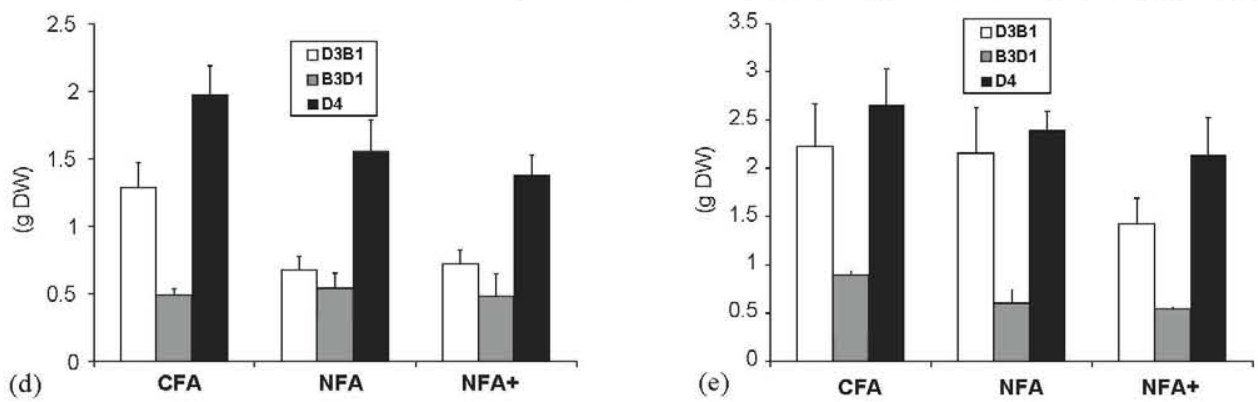

Fig. 1. Mean value and standard error for the flower production $\left(\mathrm{g} \mathrm{DW}\right.$ plant $\left.{ }^{-1}\right)$ of the different mesocosms exposed to the charcoal filtered air (CFA), non-filtered air (NFA) or non-filtered air supplemented with $40 \mathrm{nll}^{-1}$ of $\mathrm{O}_{3}$ (NFA+): (a) $T$. cherleri, 1 st flower harvest (b) T. cherleri, 2nd flower harvest, (c) T. subterraneum, (d) T. striatum, 1st flower harvest, (e) T. striatum, 2nd flower harvest. B3A1, B3D1, B3F1 = 1 clover plant of T.cherleri, T. striatum or T. subterraneum, respectively, growing with 3 B. maxima plants; A3B1, D3B1 $=3$ clover plants of $T$. cherleri or $T$. striatum, respectively, growing with 1 individual of $B$. maxima. A4, D4, F4 = monoculture of 4 plants of T.cherleri, T.striatum or T.subterraneum, respectively, DAS= Days after the start of the experiment.

Reductions of $34 \%$ and $45 \%$ were found in the flower biomass of $T$. cherleri plants grown in the NFA and NFA + treatments, respectively. Their competition with B. maxima plants showed a $53 \%$ decline in their total flower biomass. A significant interaction $(p<0.001)$ between $\mathrm{O}_{3}$ exposure and mesocosm-type was found since the flower biomass of the monocultures of this species grown in the CFA treatment was $61 \%$ greater than in those mesocosms where $T$. cherleri plants were grown with one or three B. maxima individuals. This effect was not found in the remaining two $\mathrm{O}_{3}$ treatments.

\subsection{T. subterraneum}

Ozone exposure induced a $60 \%$ reduction in the flower biomass of $T$. subterraneum (Fig. 1c) when NFA $\left(\right.$ AOT $\left.40=2228 \mathrm{nll}^{-1}\right)$ or NFA + treated $\left(14161 \mathrm{nll}^{-1}\right)$ plants were compared with those grown under CFA conditions $(p<0.05)$. Although no $\mathrm{O}_{3}$ exposure-mesocosm-type interactions were found for flower biomass, it tended to be greater $(p<0.1)$ when grown in monoculture than when growing in competition with B. maxima. 


\subsection{T. striatum}

This species had the shortest life-span of the three clover species tested and it was the most precocious regarding flower formation. The flower production of $T$. striatum was studied in two stages, just at the end of the 45-day period where the plant material was exposed in the OTCs to the different $\mathrm{O}_{3}$ treatments and once the plants had remained in the open for 30 days after their exposure in the chambers.

Forty five days after the experiment was initiated (Fig. 1d) flower output was affected by both $\mathrm{O}_{3}$ $(p<0.05)$ and by its competition with $B$. maxima $(p<0.0001)$; no interaction between these two factors was found. Flower biomass of the T. striatum plants grown in the CFA treatment was $29 \%$ greater than in those grown in the NFA (AOT40 $=2403 \mathrm{nll}^{-1} \mathrm{~h}$ ) or $\mathrm{NFA}+$ chambers $\left(\right.$ AOT $\left.40=13389 \mathrm{nll}^{-1} \mathrm{~h}\right)$. No significant differences were found between NFA and NFA + treatments. The greatest flower production was observed when $T$. striatum was grown in monoculture, followed by those in competition with a single $B$. maxima plant ( $45 \%$ reduction compared with monoculture); its least flower output ( $69 \%$ compared with monoculture) was observed when competing with three B. maxima individuals.

Seventy five days after the experiment was initiated (see Fig. 1e) no significant effects were found between the different $\mathrm{O}_{3}$ treatments. Therefore, an attenuation of $\mathrm{O}_{3}$ effects found in the previous harvest was observed once the plants remained in the open for a month. This decline in the intensity of $\mathrm{O}_{3}$ effects was apparently triggered by changes in the CFA plants after being exposed to ambient $\mathrm{O}_{3}$ levels in the open, which showed very similar responses to NFA plants. The magnitude of the response of the NFA + plants remained very similar

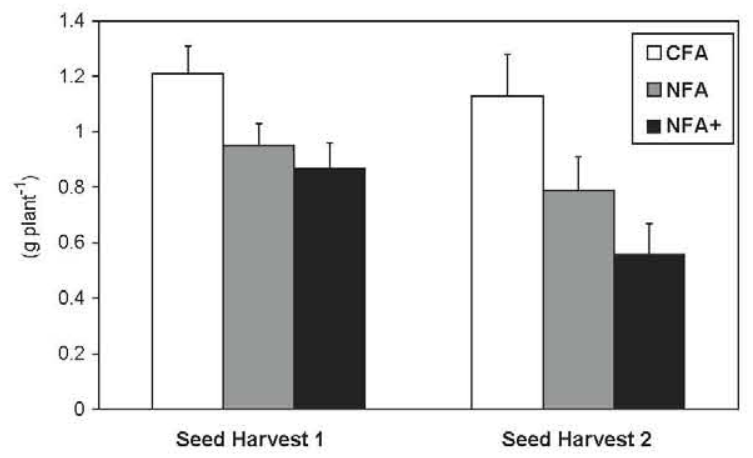

Fig. 2. Seed production of $T$. striatum plants in the two assessments that were carried out during the experiment. Each bar corresponds to the mean value and standard error of the seed output obtained for all the mesocosms under each ozone treatment $\left(\mathrm{g} \mathrm{plant}^{-1}\right) . \mathrm{CFA}=$ charcoal-filtered air; $\mathrm{NFA}=\mathrm{Non}-$ filtered air; $\mathrm{NFA}+=$ Non-filtered air supplemented with $40 \mathrm{nll}^{-1}$ of $\mathrm{O}_{3}$. in both harvests, although it was not significant in the second flower harvest, suggesting that the observed attenuation would be dependent on the $\mathrm{O}_{3}$ exposure levels the plants experienced at early stages. This attenuation influenced by early $\mathrm{O}_{3}$ exposure was also found in $T$. cherleri, where a $52 \%$ reduction in flower biomass of the NFA plants was observed in the first harvest when compared to the CFA treatment, while this difference declined to a $34 \%$ in the second flower assessment. However, this pattern was much smaller in the $T$. cherleri plants exposed in the NFA + chambers, since the reduction in their total flower biomass when compared to the CFA treatment was $52 \%$ and $45 \%$ in the first and second harvests, respectively.

The early exposure to $\mathrm{O}_{3}$ during 45 days in the OTCs brought about adverse effects in the seed output of the T. striatum plants although the two seed harvests were carried out once they remained in the open during 30 and 53 days, respectively (see Table 2). The CFA plants showed average increases for the two seed harvests of $29 \%$ and $41 \%$ when compared with NFA or NFA + plants, respectively (see Fig. 2). The beneficial effect of charcoal filtration on the seed output was in the same range as for the total flower biomass harvested 30 days

Table 2

Results of the two-way ANOVA statistical test performed to assess the effects of mesocosm, ozone exposure and their interactions on the seed output of $T$. striatum

\begin{tabular}{lll}
\hline Factors & $\begin{array}{l}\text { 1st seed harvest } \\
(\mathrm{g})\end{array}$ & $\begin{array}{l}\text { 2nd seed harvest } \\
(\mathrm{g})\end{array}$ \\
\cline { 2 - 3 } Mesocosms & $<0.0001$ & $<0.0001$ \\
$\mathrm{O}_{3}$ & 0.02 & 0.007 \\
Mesocosms $\times \mathrm{O}_{3}$ & $\mathrm{~ns}$ & $\mathrm{~ns}$ \\
\hline $\mathrm{B} 3 \mathrm{D} 1$ & & \\
CFA & $0.44 \pm 0.05$ & - \\
NFA & $0.23 \pm 0.15$ & - \\
NFA + & $0.25 \pm 0.03$ & - \\
& & \\
D3B1 & & $0.41 \pm 0.13$ \\
CFA & $1.04 \pm 0.15$ & $0.18 \pm 0.03$ \\
NFA & $0.75 \pm 0.10$ & $0.12 \pm 0.02$ \\
NFA + & $0.73 \pm 0.09$ & \\
D4 & & $1.37 \pm 0.10$ \\
CFA & & $0.99 \pm 0.09$ \\
NFA & $1.32 \pm 0.18$ & $0.70 \pm 0.11$ \\
NFA + & $1.20 \pm 0.08$ & \\
\hline
\end{tabular}

Mean \pm standard error for the different mesocosms and ozone treatments are provided. $\mathrm{CFA}=$ charcoal-filtered air; $\mathrm{NFA}=$ Non-filtered air; NFA $+=$ Non-filtered air supplemented with $40 \mathrm{nll}^{-1}$. B3D1 $=1$ clover plant of the same species growing with 3 B. maxima plants; D3B1 $=3$ clover plants growing with 1 individual of $B$. maxima. D4-monoculture of 4 plants of $T$. striatum. 
earlier, suggesting a great relationship between these two parameters.

The $T$. striatum plants grown in competition with 3 B. maxima individuals showed a $69 \%$ decline in flower biomass when compared with the remaining two mesocosms. The intensity of interspecific competition induced a significant gradation in plant seed production corresponding to the first assessment, when compared with $T$. striatum monocultures: a reduction of $29 \%$ in seed weight was found when competing with a single Briza plant, increasing to $74 \%$ when competing with three Briza plants. An enhancement of this competitive effect was found at the last harvest since a $76 \%$ seed weight reduction was observed in the 3D1B mesocosm. No ozone exposure-competition interactions were found for total flower biomass or total seed weight at any stage of the experiment.

\subsection{Combined analysis of the response of the three clover species}

Since $\mathrm{O}_{3}$ exposure determined significant reductions in the flower biomass of the three clover species a combined analysis of their response was carried out to find out whether common patterns could be derived for these species. Ozone and mesocosm significantly affected the flower production of the three species (Fig. 3). Ozone caused a significant reduction $(p<0.001)$ in the flower biomass of the three species, being $27 \%$ and $34 \%$ greater in the CFA treatment than in the NFA and NFA+ treatments, respectively. Their competition with 1 and 3

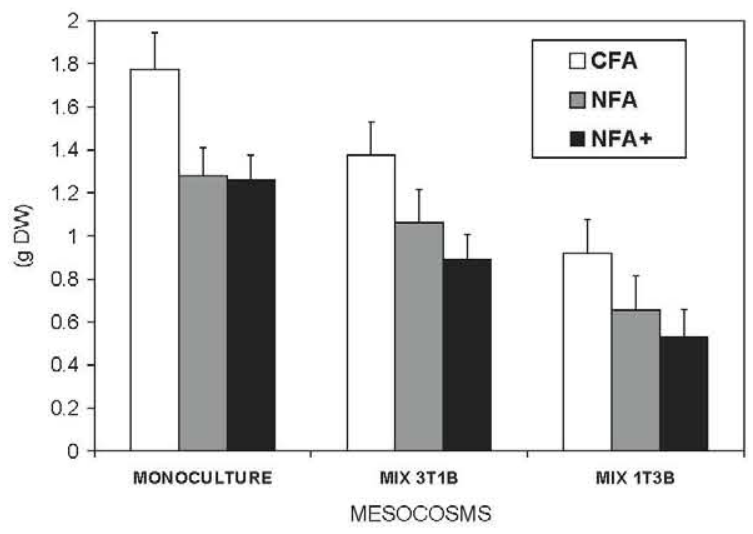

Fig. 3. Mean values and standard errors of the total flower biomass ( $\mathrm{g} \mathrm{DW}$ plant ${ }^{-1}$ ) of the three clover species involved in the experiment when grown under different competitive situations and different ozone exposure regimes. Monoculture $=4$ clover plants of a given species; Mix $3 \mathrm{~T} 1 \mathrm{~B}=3$ clover plants of the same species growing with a single B. maxima plant; Mix $1 \mathrm{~T} 3 \mathrm{~B}=1$ clover plant growing with 3 individuals of $B$. maxima. CFA $=$ charcoal-filtered air; NFA $=$ Non-filtered air; NFA $+=$ Non-filtered air supplemented with $40 \mathrm{nll}^{-1}$ of $\mathrm{O}_{3}$.
B. maxima plants also induced $23 \%$ and $51 \%$ reductions $(P<0.0001)$ in their flower biomass when compared to the values obtained in monocultures. No significant $\mathrm{O}_{3}$ $x$ mesocosm interactions were found.

The results of this experiment indicate the great sensitivity to $\mathrm{O}_{3}$ of the three clover species assessed in this study. This is a finding of concern since it is the most predominant taxon in therophytic and siliceous pastures of the Iberian peninsula (Allué Andrade and Tella, 1986). When plants of these species were protected from ambient or above-ambient $\mathrm{O}_{3}$ levels for 45 days, a beneficial effect on flower output was observed. The $\mathrm{O}_{3}$ induced detrimental effects on flower biomass corresponded with AOT40 values in the range of 2200 $2700 \mathrm{nll}^{-1} \mathrm{~h}$ for just 45 days, corresponding to a similar daily $\mathrm{O}_{3}$ accumulation rate than that provided by the present $\mathrm{O}_{3}$ critical level for the protection of seminatural vegetation of $3000 \mathrm{nll}^{-1} \mathrm{~h}$ for a three month period (Ashmore and Franzaring, 2003). However, AOT40 was not the best exposure index in explaining the response in the flower biomass found in this experiment whether considering just the period where plants remained in the OTCs or their overall exposure to this pollutant until the flowers were harvested (see Table 3). In general, those indices based on averages for different periods ranging from hours to a day (M10, M24, D33) and the indices considering $30 \mathrm{nll}^{-1}$ as a cut-off (NUM30, AOT30) performed better $(-0.86<r<-0.75)$ than those indices considering cut-offs $\geqslant 60 \mathrm{nll}^{-1}$ (AOT60 and NUM60)

Table 3

Pearson's correlation indices $(* p<0.05, * * p<0.01)$ between different ozone exposure indices and the total flower biomass of relative to control for the three clover species involved in the experiment

\begin{tabular}{lll}
\hline $\begin{array}{l}\text { Ozone exposure } \\
\text { index }\end{array}$ & $\begin{array}{l}\text { OTC exposure } \\
\text { period (45 days) }\end{array}$ & $\begin{array}{l}\text { Total exposure } \\
\text { period }(45-102 \\
\text { days) }\end{array}$ \\
\hline AOT30 & $-0.75^{* *}$ & $-0.78^{* *}$ \\
AOT40 & $-0.66^{* *}$ & $-0.70^{* *}$ \\
AOT60 & $-0.54^{*}$ & $-0.59^{*}$ \\
NUM30 & $-0.86^{* *}$ & $-0.83^{* *}$ \\
NUM40 & $-0.83^{* *}$ & $-0.83^{* *}$ \\
NUM60 & $-0.61^{*}$ & $-0.66^{*}$ \\
M10 & $-0.83^{* *}$ & $-0.81^{* *}$ \\
M24 & $-0.84^{* *}$ & $-0.81^{* *}$ \\
D33 & $-0.84^{* *}$ & $-0.86^{* *}$ \\
NUM100 & $-0.55^{*}$ & $\mathrm{~ns}$ \\
\hline
\end{tabular}

AOT30, AOT40, AOT60 = accumulated exposure over the cutoff of 30,40 and $60 \mathrm{nl}^{-1}$, respectively, NUM30, NUM40, NUM60 $=$ number of hours presenting $\mathrm{O}_{3}$ levels above 30,40 and $60 \mathrm{nll}^{-1}$, respectively, $\mathrm{M} 10=\mathrm{O}_{3}$ 10-hour mean from 07:00 to 17:00 GMT, M24=24-h $\mathrm{O}_{3}$ mean, D33-number of days where the $\mathrm{O}_{3}$ daily mean exceeded $33 \mathrm{nll}^{-1}$, NUM100 = number of hourly averages exceeding $100 \mathrm{nll}^{-1}$. 
$(-0.54<r<0.61)$. It appears that $\mathrm{O}_{3}$ concentrations, regardless of their range, might be equally harmful for these species suggesting that no $\mathrm{O}_{3}$ threshold should be considered for their protection, as previously reported by Bermejo et al. (2003) concerning the development of foliar visible injury. This fact is supported by the better performance of the index that considered the number of hours the plants were exposed to $40 \mathrm{nll}^{-1}$ (NUM40) when compared to the AOT40 index, which indirectly provides more weight to the highest $\mathrm{O}_{3}$ concentrations (Tuovinen, 2000). This dataset should be combined with other experimental results to ascertain whether this applies to other seminatural species, too.

It can be concluded that early $\mathrm{O}_{3}$ exposure and competition influence the reproductive ability of the studied clover species. The lack of interaction between these two factors generally found in this experiment could be explained by the great sensitivity of the clover populations used in the study and because $B$. maxima was a very strong competitor for the three clover species as derived from biomass-related parameters (data not shown). Other studies are under way involving competition with other species to evaluate whether it modulates plant response to $\mathrm{O}_{3}$ exposure.

The results of this study have important ecological implications. Plant composition of these therophyteprevailing systems is greatly dependent on the belowground seed pool (Peco et al., 1998a, b). Therefore the seed output of therophytes is crucial for their perpetuation. Ozone exposure appears to interfere with this process by affecting the reproductive ability of sensitive species even at rather low $\mathrm{O}_{3}$ levels for just 45 days. Thus, $\mathrm{O}_{3}$ exposure might affect the seed production of therophytes, which would induce an adverse impact on the species composition of these ecosystems. Field trials following $\mathrm{O}_{3}$ exposure gradients are envisaged to test whether this experimental observation actually occurs under field conditions. Further research will concentrate in the assessment of $\mathrm{O}_{3}$ effects on seed viability and the interactive effects of this pollutant and other environmental stresses on plant fitness.

\section{Acknowledgements}

This research was conducted under the framework of the ICP-Vegetation and was funded by the EU BIOSTRESS project, Contract EVK2-C-1999-00040, and the agreement between the Spanish Ministry of Environment and CIEMAT on "Critical loads and levels". Thanks are given to Dr. César Gómez Campos (ETSIA, Madrid) and Dr. Francisco González López (Servicio de Investigación y Desarrollo Tecnológico, DG. de Producción, Investigación y Formación Agraria, Consejería de Agricultura y Medio Ambiente de la Junta de Extremadura).

\section{References}

Allué Andrade, J.L., Tella, G., 1986. Los pastos españoles. II. Clasificación, composición, atributos y mejora de sus principales tipos florísticos. E.U.I.T. Forestal, Madrid, Spain.

Alonso, R., Elvira, S., Castillo, F.J., Gimeno, B.S., 2001. Interactive effects of ozone and drought stress on pigments and activities of oxidative enzymes in Pinus halepensis. Plant Cell and Environment 24, 905-916.

Ashmore, M., Franzaring, J., 2003. Report from the working group on semi-natural vegetation. In: Karlsson, P.E., Selldén, G., Pleijel, H. (Eds.), Establishing ozone critical levels II, UN ECE Workshop report, IVL Report B 1523, $379 \mathrm{pp}$.

Ashmore, M.R., Thwaites, R.H., Aisnworth, N., Cousins, D.A., Power, S.A., Morton, J., 1995. Effects of ozone on calcareous grassland communities. Water, Air and Soil Pollution 85, 1527-1532.

Bermejo, V., Gimeno, B.S., Sanz, J., de la Torre, D., Gil, J.M., 2003. Assessment of the ozone sensitivity of 22 native plant species from mediterranean annual pastures based on visible injury. Atmospheric Environment 37, 4667-4677.

Black, V.J., Black, C.R., Roberts, J.A., Stewart, C.A., 2000. Impact of ozone on the reproductive development of plants. New Phytologist 147, 421-447.

Bungener, P., Balls, G.R., Nussbaum, S., Geissmann, M., Grub, A., Fuhrer, J., 1999. Leaf injury characteristics of grassland species exposed to ozone in relation to soil moisture condition and vapour pressure deficit. New Phytologist 142, 271-282.

Davison, A.W., Barnes, J.D., 1998. Effects of ozone on wild plants. New Phytologist 139, 135-151.

De Witt, C.T., 1960. On competition. Verslagen van Landouwkundige Onderzoekingen $66,1-82$.

EMEP, 2002. Transboundary acidification, eutrophication and ground level ozone in Europe. EMEP Report 1 and 2/2002. EMEP, Oslo, Norway.

Fuhrer, J., Shariat-Madari, H., Perler, R., Tschannen, W., Grub, A., 1994. Effects of ozone on managed pasture. II. Yield, species composition, canopy structure and forage quality. Environmental Pollution 83, 317-325.

Fuhrer, J., Ashmore, M.R., Mills, G., Hayes, F., Davidson, A.W., 2003. Ozone critical levels for semi-natural vegetation. In: Karlsson, P.E., Sellden, G., Pleijel, H. (Eds.), Establishing Ozone Critical Levels. II UNECE Workshop Report. IVL Report B 1523. IVL Swedish Environmental Research Institute, Gothenburg, Sweden, pp. 183-198.

Gimeno, B.S., Bermejo, V., Reinert, R.A., Zheng, Y., Barnes, J.D., 1999. Adverse effects of ambient ozone on watermelon yield and physiology at a rural site in eastern Spain. New Phytologist 144, 245-260.

Hamilton, N.R.S., 1994. Replacement and additive designs for plant competition studies. Review. Journal of Applied Ecology 31, 599-603.

Madkour, S.A., Laurence, J.A., 2002. Egyptian plant species as new ozone indicators. Environmental Pollution 120, $339-353$.

Marañón, T., 1988. Agro-sylvo-pastoral systems in the Iberian Peninsula: Dehesas and Montados. Rangelands 10, 255-258. 
Myers, N., Mittermeier, R.A., Mittermeier, C.G., da Fonseca, C.A.B., Kent, J., 2000. Biodiversity hotspots for conservation prioirities. Nature 403, 853-858.

Nussbaum, S., Geissmann, M., Fuhrer, J., 1995. Ozone exposure relationships for mixtures of perennial ryegrass and white clover depend on ozone exposure patterns. Atmospheric Environment 29, 989-995.

Palacios, M., Kirchner, F., Martilli, A., Clappier, A., Martín, F., Rodríguez, M.E., 2002. Summer ozone episodes in the greater Madrid area. Analyzing the ozone response to abatement strategies by modelling. Atmospheric Environment 36, 5323-5333.

Peco, B., Espigares, T., Levassor, C., 1998a. Trends and fluctuations in species abundance and richness in Mediterranean annual pastures. Applied Vegetation Science 1, 21-28.

Peco, B., Ortega, M., Levassor, C.M., 1998b. Similarity between seed bank and vegetation in Mediterranean grasslands: a predictive model. Journal Vegetation Science 9, $815-828$

Pineda, F.D., Nicolás, J.P., Ruiz, M., Peco, B., Bernáldez, F.G., 1981. Succesion, diversité et amplitude de niche dans les aturages du centre de la péninsule ibérique. Vegetatio 47, $267-277$.
Plaza, J., Pujadas, M., Artínano, B., 1997. Formation and transport of the Madrid ozone plume. Journal of Air and Waste Management Association 47, 666-774.

Sala, O.E., Chapin III, F.J., Armesto, J.J., Berlow, E., Bloomfield, J., Dirzo, R., Huber-Sanwald, E., Huenneke, L., Jackson, R.B., Kinzig, A., Leemans, R., Lodge, D., Mooney, H., Oesterheld, M., Poff, N.L., Sykes, M.T., Walker, B.H., Walker, M., Wall, D.H., 2000. Global diversity scenarios for the year 2100. Science 287, 1770-1774.

Snaydon, R.W., 1991. Replacement or additive design for competition studies. Journal of Applied Ecology 28, 930-946.

Tuovinen, J.P., 2000. Assessing vegetation exposure to ozone: properties of the AOT40 index and modifications by deposition modelling. Environmental Pollution 109, 361-372.

UN ECE, 1988. ECE Critical Levels Workshop. Bad Harzburg 14-18 March 1988. Final Draft Report. Unwelbundesamt, Berlin, Germany.

Warwick, T., Taylor, G., 1995. Contrasting effects of tropospheric ozone on five native herbs which coexist in calcareous grassland. Global Change Biology 1, 143-151. 